\title{
ANALYSIS OF THE IMPACT OF FINANCIAL STATEMENTS QUALITY ON PUBLIC ACCOUNTABILITY
}

\author{
Mayanih ${ }^{1+}$ \\ Hari Setiyawati ${ }^{2}$
}

\author{
${ }^{1,2}$ Department of Accounting Universitas Mercu Buana, Jakarta, Indonesia. \\ ${ }^{i}$ Email: withmsyanie@gmail.com Tel:0812-8130-5548 \\ 'Email: hari_setivawati@mercubuana.ac.idTel:0859-2109-1374
}

\section{,}

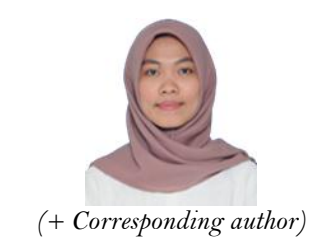

ABSTRACT

\section{Article History}

Received: 6 August 2020 Revised: 18 September 2020 Accepted: 30 September 2020 Published: 15 October 2020

\section{Keywords}

Organizational commitments Implementation of internal Control systems

Accounting understandability Quality of financial statements Public accountability.

\begin{abstract}
The lack of compliance with the quality standards of financial reports indicates weak accountability. The BPK found a deviation in South Tangerang City Government budget up to 1.7 billion rupiahs in the 2017 fiscal year; this incident shows the 2017 WTP achievement does not reflect the quality of accountable financial reports. This study aims to examine the influence of organizational commitments, implementation of internal control systems, and accounting understandability towards the quality of financial statements and their impact on public accountability. The population of this study is a Regional Working Unit (SKPD) in South Tangerang City. The sampling technique used a saturation non-probability sampling method and obtained 36 samples. The results reveal that organizational commitment has no significant effect on the quality of financial statements, while the application of internal control systems and accounting understandability has a significant effect on the quality of financial statements. The quality of financial reports has a significant impact on public accountability.
\end{abstract}

Contribution/ Originality: The papers primary contribution is finding that the importance of employees to understand public sector accounting standards that are in accordance with Indonesian regulations in order to produce quality financial reports that can increase public trust.

\section{INTRODUCTION}

The increase of public demands toward public institutions for governing the central and regional government, particularly in implementing financial supervision, has encouraged the regional government to implement public accountability as an obligation. The regional government as a reporting entity that consists of one or more than one accounting entities, is required to submit a report of accountability, which is stated in Law No. 17 of 2013 that obligates the regional head to present regional financial statements as a liability. The quality of financial reporting can be seen from the qualitative characteristic of a financial statement. According to government regulation No. 71 of 2010, which is a normative requirement as mentioned in Conceptual Numerals of Government Accounting that can be comprehended, relevant, reliable, and comparable. However, the Indonesian Institute of Accountants (IAI) stated that financial reporting practices still do not meet the qualitative characteristics as mentioned in the conceptual numerals of government accounting. Whereas, qualitative characteristics of financial statements are the 
essential attribute that causes the information in the financial statement useful for the users in making a decision (Hery, 2016).

Public Accountability (Public accountability) is the main cornerstone of a good governance process. This principle is necessary because the government bureaucracy must account for its actions and policies to the public. According to Mursyidi (2009) to create accountability, the presented financial statements should be qualified because to know the position and financial performance of an entity, can be seen in its financial report. One of the biggest obstacles to realizing the report quality is the low organizational commitment of the employee's financial statements. Yet the success of the organization is determined by the level of competence, and its commitment to the work. By the existence of organizational commitment, it will maintain compliance in presenting financial statements to improve the quality of financial report reliability (Sugandi \& Hanif, 2013). Unfulfilled quality standards of financial statements show weak accountability. When accountability demands are not fulfilled, it indicates a weak system which further affects the culture of systemic corruption.

Based on data found by the Audit Board of the Republic of Indonesia in conducting an audit of government's financial statements throughout the year 2018, 2,259 civil servants in some regions were entangled in corruption cases, one of which occurred to the government of South Tangerang which involved seven civil servants being fired for a corruption case. The data found by the Financial Audit Board in 2018 is not different from the results found by the Audit Board in the first semester of 2017 that indicated that the regional government has not implemented the regulation to reporting financial statements. There were 4,997 issues found, including 7,284 (49\%), which is a matter of weakness in internal control systems (SPI). A weak internal control system will cause the financial report quality decline so that it will impact the reliability and timeliness of the report. According to Mahmudi (2006) poor financial statements cause the users of financial statements to obtain false and misleading information, so it leads to an error in making a decision. Therefore, competent human resources are required with an academic background in accounting education and experience in finance, especially in regional and organizational finance about government. The failure of human resources in understanding and implementing accounting logic will have an impact on the misrepresentation of the presented financial statements and report discrepancies with the standards set by the government (Warisno, 2008).

The problem formulation in this research is to analyze whether the organizational commitments, implementation of internal control systems, and accounting comprehension have a significant effect on the quality of financial reporting, and what are the impacts on public accountability. This study aims to examine the significant influence of organizational commitment, the implementation of internal control systems, and the understanding of accounting for the quality of financial statements and their impact on public accountability.

\section{LITERATURE REVIEW}

\subsection{Organizational Commitments}

According to Kusumaputri (2015) organizational commitment is the level of willingness of individuals to maintain their membership because of their conformity and interest in the goals and values of the organization. Baldwin (2013) defines organizational commitment is an attitude that represents the extent to which an employee identifies his organization and the desire to remain as a member of the organization.

Robbins and Judge (2009) stated that organizational commitment is a condition where an employee sides with a particular organization and the goals of his desire to maintain membership in the organization. Commitment to the organization is shown by the strong desire to maintain organizational membership, accept the values and goals of the organization, and be willing to strive for the achievement of the organizational goals.

According to Luthans (2011) in Wibowo (2017) organizational commitment is often defined as (a) a strong desire to remain a particular member, (b) a desire to urge business at a high level on behalf of the organization, and (c) definite confidence in and acceptance of the organization's values and goals. In other words, commitment is an 
attitude that reflects employee loyalty to the organization and is an ongoing process through which organizational participants express their concern for the organization and its continued success and prosperity.

\subsection{The Implementation of Internal Control System}

The internal control system is an action taken on financial and non-financial to ensure the protection of assets, detection, and prevention of fraud, meet the requirements and procedures for internal control policies, and accuracy of completeness (Abiola \& Oyewole, 2013). Reeve, Carls, and Fees (2013) defines internal controls as "internal controls are the policies and procedures that protect assets from misuse, ensure that business information are accurate, and ensure that laws and regulations are being followed".

Arens (2006) stated that "Internal control includes five categories of controls that management design and implements to provide reasonable assurance that Management's control objectives win be met. These are the component of internal control; (1) Control Environment, (2) Risk Assessment, (3) Information and Communication, (4) Control Activities, (5) Monitoring.

The internal control system includes organizational structure, methods, and measurements that are coordinated to maintain the organization's wealth, check the accuracy and reliability of accounting data, promote efficiency and encourage compliance with management policies. The definition of the internal control system emphasizes the objectives to be achieved, and not on the elements that make up the system. Thus, the definition of internal control above applies both in companies that process information manually, with accounting machines and with computers (Mulyadi, 2014).

\subsection{Accounting Comprehension}

According to the Government Regulation No. 24 of 2005 about Government Accounting Standards article 1 states that accounting is the process of recording, measuring, classifying, summarizing transactions and financial events, interpreting the results, and presenting reports. Someone can be categorized to understand accounting when they comprehend and understand how the accounting process is carried out until it becomes a financial report based on the principles and standards for preparing financial statements that are applied in Government Regulation No. 24 of 2005 about Government Accounting Standards, Aniftahudin, Kamaliah, and Hanif (2016).

KBBI (Kamus Besar Bahasa Indonesia) (2005) defines comprehend as an intelligent and true understanding, while comprehension is a process to comprehend or to give a comprehension. People who have a comprehension of accounting are those who truly understand how the accounting process is carried out to be a valid financial statement and based on the principles and standards of prevailing financial statements preparation Yulianani, Nadirsyah, and Bakar (2010).

Aniftahudin et al. (2016) mentioned that to measure a person's comprehension can be seen from several aspects, i.e: (1) Education, education is a conscious and planned effort to create a learning atmosphere and process in such a way that students can actively develop their potential to have self-control, intelligence, social skills, spiritual strength, personality, and noble character. (2) Training, training is one of the efforts in improving the quality of human resources at work. Employees, whether new or already employed, need to take part in training because of the demands of work that can change due to changes in the work environment and strategies. (3) The level of experience, the experience can also be interpreted as episodic memory, the memory that receives and stores events that occur or are experienced by individuals at a particular time and place, which serves as a reference. Experience is a person's ability that gained in the past so that it becomes a skill to do the job without hesitation.

\subsection{Quality of Financial Report}

Iman (2010) defined quality as conformity with standards, measured based on the level of conformity, and achieved through inspection. Financial reporting is a structure and process that describes how financial information 
is provided and reported to achieve financial reporting objectives that will help in achieving the country's economic and social goals (Suwardjono, 2005). Thomas, Henny, Elaine, and Michael (2009) mentioned that three things indicate the high quality of financial reporting, i.e: (a) completeness, (b) unbiased measurement (c) clear presentation.

Financial statements are structured reports about the financial position and transactions carried out by a reporting entity. Government regulation No. 71 of 2010 explains the qualitative characteristics of financial statements are normative measures that need to be actualized in accounting information so that it can achieve its objectives. The quality of a financial statement is determined by the qualitative characteristics of the financial statements that contained in PP No. 71 of 2010, i.e: 1) relevant; information must be relevant to meet the users' needs in the decision making process 2) reliable; free from misleading notions, material errors and the wearer's reliability 3) can be comprehended; its ease of being comprehended by users 4) can be compared; can compare financial statements between periods.

\subsection{Public Accountability}

Mahmudi (2015) defines public accountability as an obligation of the agent (government) to manage resources, report, and disclose all activities and activities related to the use of public resources to the creditor. The importance of accountability in an organization should always be acknowledged by the local government as a necessity to achieve its vision or goals. Accountability will only be achieved if all workers are committed to achieving organizational goals.

According to Bastian (2010) public accountability is mandatory to convey accountability or to respond, describe the performance, and actions of a person or legal entity and a collective leader or organization to those who have the right or authority to request information or accountability.

Public accountability is the obligation of the agent to provide liability, present, report, and disclose all activities and activities that are his responsibility to the principal that has the right and obligation to request accountability (Mardiasmo, 2009).

Public accountability (public accountability) is the main foundation for good governance process. This principle is necessary because the government bureaucracy must be accountable for its actions and policies to the public. Public accountability as one of the main principles in creating good governance (good governance) is an important determinant in improving the performance of public bureaucracy (Rakhmat, 2018).

\section{HYPOTHESIS DEVELOPMENT}

Organizational commitment can be created if the people involved in the organization have a strong desire to achieve the organization's vision and mission. Istri, Prami, Made, and Erawati (2017) stated that if the organizational commitment in each Regional Working Unit (SKPD) is excellent, it will affect the results of the unit's financial statements. This case indicates that if the organizational commitment of a Regional Working Unit (SKPD) is good, it will also affect in generating a good financial report. Research conducted by Istri et al. (2017) revealed that organizational commitment affects the quality of financial statements. Aligned with this result, Rommy (2011) and Ivano (2009) mentioned that high commitment can generate good performance. Based on the description above, it can be concluded that organizational commitment can significantly affect the quality of financial statements.

H1: Organizational Commitment significantly affect the quality of financial statements.

The internal control system related to financial statements is a process that is designed to provide adequate confidence in the reliability of financial statements and appropriate presentation under accounting principles in Indonesia, compliance with applicable laws and regulations, and operation improvement effectively and efficiently. Research conducted by Trisnawati and Wiratmaja (2018); Herawati (2014) and Djalil, Nadir, and Fatmi (2017) 
showed that the application of an internal control system has a significant effect on the quality of local government financial reports. While the results of research conducted by Setiyawati (2013) and Nurlis and Winwin (2017) revealed the results that the internal control system does not affect the quality of financial statements. Based on the description above, it can be formulated that the application of the internal control system has a significant effect on the quality of the financial statements.

H2: The implementation of the Internal Control System has a significant impact on the quality of financial statements.

In excellent regional financial management, the Regional Working Unit (SKPD) must have competent human resources. This is essential because in creating high-quality regional financial reports requires qualified human resources that not only understand about compiling the financial statements but also understand how the governmental accounting works, particularly in regional finance and organizational about government. Research conducted by Purwanti and Wasman (2016) revealed that accounting comprehension has a positive effect on the quality of financial statements. In line with research conducted by Aniftahudin et al. (2016) which showed that accounting comprehension has a positive influence on the quality of financial statements. Based on the description above, it can be concluded that accounting comprehension has a significant impact on the quality of financial statements.

H3: Accounting Comprehension significantly influence the quality of financial statements.

Financial statements are an essential component in creating public accountability. Mursyidi (2009) stated that knowing the position and financial performance of an entity can be seen in its financial statements. Therefore, to create public accountability, local governments are required to present transparent financial statements that are equipped with adequate disclosure of information that can be used as a basis for decision making. The concept contained in accountability is not limited to accountability reports, but also included the practical practices for the mandate givers to obtain information transparently. Research conducted by Iskandar and Setiyawati (2015) and Djalil et al. (2017) stated that quality financial reports have a positive impact on public accountability, the more qualified a financial report, the better impact gained towards public accountability. Based on the description above, it can be formulated that the quality of financial statements has a significant influence on public accountability.

H4: The quality of financial statements has a significant impact on public accountability.

The framework of how this study conducted is represent in the following Figure 1.

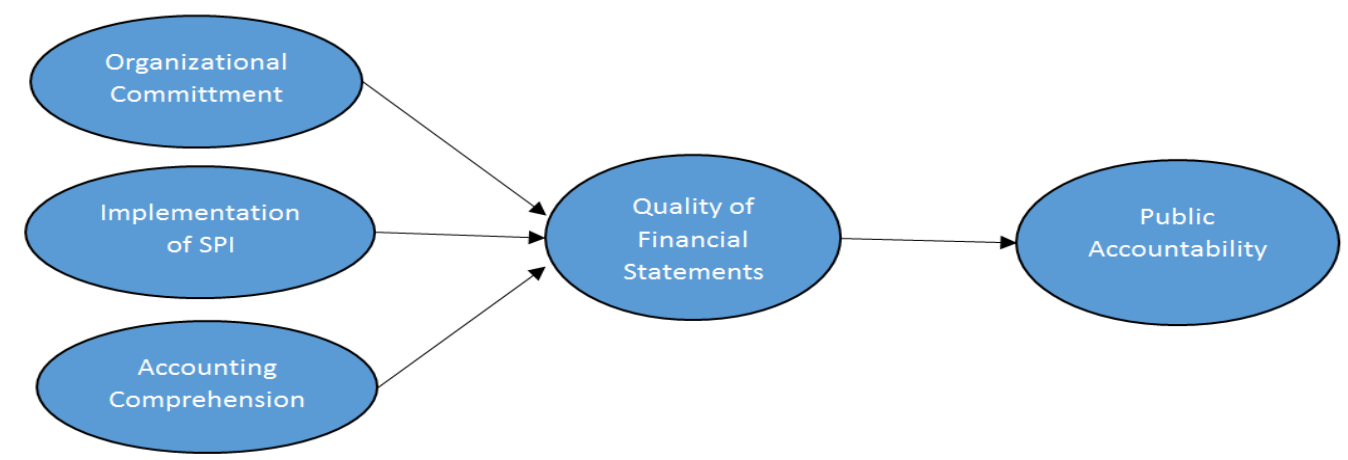

Figure-1. Theoretical framework.

\section{RESEARCH METHOD}

In analyzing the data, the researcher used casual analysis, which aims to examine whether one variable causes other variables to change or not, by testing the hypothesis by using the Equation Model Structure (SEM) with the Partial Least Square (PLS) approach. The selection process in this model was based on the number of samples below 50, and in the SEM PLS Model, the measurement model is formed by a variable that has a reflexive indicator. In this reflexive indicator model, indicators on one board (latent variable) were influenced by the same concept. 
SEM PLS models included inner models (structural models) and outer models (measurement models). The data used were primary data collected through instruments in the form of questionnaires.

This data was processed by using SmartPls 3.0 software. The population in this study were all regional work units in South Tangerang City. The sampling technique used was Non-Probability Sampling by using a saturated sample method, so that from the 36 populations that were used to be the entire sample. Respondents used in this study were employees of the finance department. The variables in this study were measured using the second-order confirmation analysis method. Table 1 presents a summary of the measurement tables for each variable as follows:

Table-1. Definition of variable operationalization.

\begin{tabular}{|c|c|c|c|}
\hline Variable & Dimension & Indicator & Scale \\
\hline \multirow{5}{*}{$\begin{array}{l}\text { Public Accountability } \\
(Z) \\
\text { Mahmudi (2015) }\end{array}$} & $\begin{array}{l}\text { 1. Legal Accountability } \\
\text { and Honesty }\end{array}$ & $\begin{array}{l}\text { 1. Compliance with the law } \\
\text { 2. Avoidance in corruption and } \\
\text { collusion }\end{array}$ & Interval \\
\hline & $\begin{array}{l}\text { 2. Managerial } \\
\text { Accountability }\end{array}$ & $\begin{array}{l}\text { 1. Management of the } \\
\text { organization effectively and } \\
\text { efficiently. } \\
\text { 2. Accountability for } \\
\text { implementing organizational } \\
\text { activities } \\
\text { 3. Accountability for } \\
\text { performances report. } \\
\text { 4. Achievement of efficient } \\
\text { activities }\end{array}$ & Interval \\
\hline & 3. Program Accountability & $\begin{array}{l}\text { 1. Program Accountability } \\
\text { 2. The objectives of effective } \\
\text { programs }\end{array}$ & Interval \\
\hline & 4. Policy Accountability & $\begin{array}{l}\text { 1. Objective Accountability } \\
\text { 2. Policy Accountability }\end{array}$ & Interval \\
\hline & 5. Financial Accountability & $\begin{array}{l}\text { 1. Compiling regular report } \\
\text { 2. Creating annual report } \\
\text { 3. Accountability of funds } \\
\text { effectively and efficiently. } \\
\text { 4. Report publication }\end{array}$ & Interval \\
\hline \multirow{4}{*}{$\begin{array}{l}\text { Quality of Financial } \\
\text { Statements (Y) } \\
\text { Mursyidi (2013) }\end{array}$} & 1. Relevant & $\begin{array}{l}\text { 1. Has the benefit of feedback } \\
\text { (feedback value) } \\
\text { 2. Has a predictive value } \\
\text { 3. Reliable financial statements } \\
\text { 4. Complete and accurate } \\
\text { financial statements }\end{array}$ & Interval \\
\hline & 2. Reliable & $\begin{array}{l}\text { 1. Honest presentation } \\
\text { 2. Can be verified and } \\
\text { reasonable } \\
\text { 3. Neutrals } \\
\text { 4. Impartial information on } \\
\text { financial statements }\end{array}$ & Interval \\
\hline & 3. Comparable & $\begin{array}{l}\text { 1. External and Internal } \\
\text { Comparison } \\
\text { 2. Compilation of accounting } \\
\text { policies according to SAP }\end{array}$ & Interval \\
\hline & 4. Understandable & $\begin{array}{l}\text { 1. Limits of understanding } \\
\text { and users } \\
\text { 2. Financial statements have } \\
\text { values and benefits }\end{array}$ & Interval \\
\hline \multirow{2}{*}{$\begin{array}{l}\text { Organizational } \\
\text { Commitment } \\
\text { (X1) } \\
\text { Stephen and Timothy } \\
(2011)\end{array}$} & 1. Affective Commitment & $\begin{array}{l}\text { 1. Strong willingness } \\
\text { 2. Desire Work } \\
\text { 3. Believe and accept }\end{array}$ & Interval \\
\hline & $\begin{array}{l}\text { 2. Continuous } \\
\text { Commitment }\end{array}$ & $\begin{array}{l}\text { 1. Trust and acceptance } \\
\text { 2. Willingness to try } \\
\text { 3. Strong attachment }\end{array}$ & Interval \\
\hline
\end{tabular}


International Journal of Asian Social Science, 2020, 10(10): 623-637

\begin{tabular}{|c|c|c|c|}
\hline & 3. Normative commitment & $\begin{array}{l}\text { 1. Employee's Inclination } \\
\text { 2. Employee's Loyalty } \\
\text { 3. Employee's Pride }\end{array}$ & Interval \\
\hline \multirow{5}{*}{ 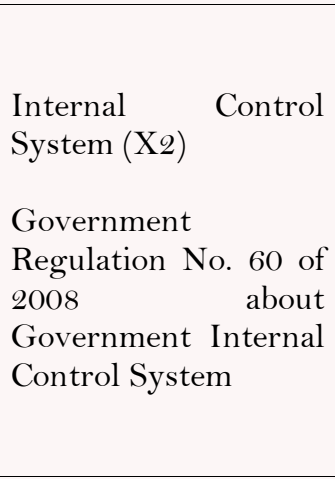 } & 1. Control Environment & $\begin{array}{l}\text { 1. Inspection of accounting } \\
\text { records } \\
\text { 2. Competency standards }\end{array}$ & Interval \\
\hline & 2. Risk Assessment & $\begin{array}{l}\text { 1. Risk Analysis } \\
\text { 2. Management Plan }\end{array}$ & Interval \\
\hline & 3. Control Activities & $\begin{array}{l}\text { 1. Physical protection } \\
\text { 2. Identification development } \\
\text { plan }\end{array}$ & Interval \\
\hline & $\begin{array}{l}\text { 4. Information and } \\
\text { Communication }\end{array}$ & $\begin{array}{l}\text { 1. Effective information delivery } \\
\text { 2. Accountability }\end{array}$ & Interval \\
\hline & 5. Monitoring & $\begin{array}{l}\text { 1. Follow up the findings } \\
\text { 2. Re-check and evaluate }\end{array}$ & Interval \\
\hline $\begin{array}{l}\text { Accounting } \\
\text { Comprehension (X3) } \\
\text { Mursyidi (2010) }\end{array}$ & $\begin{array}{l}\text { 1. Steps of } \\
\text { Accounting Cycle }\end{array}$ & $\begin{array}{l}\text { 1. Recording } \\
\text { 2. Classifying } \\
\text { 3. Summarizing } \\
\text { 4. Reporting } \\
\text { 5. Interpretation }\end{array}$ & Interval \\
\hline
\end{tabular}

\section{RESEARCH FINDING AND DISCUSSION}

\subsection{Description of Research Variables}

The following table is a descriptive analysis of the organizational commitment variables.

Table-2. Variable description Organizational Commitment.

\begin{tabular}{|c|c|c|c|}
\hline No. & Dimension & Indicator & Average \\
\hline 1 & \multirow{3}{*}{ Affective Commitment } & Strong willingness & 3.46 \\
\hline 2 & & Desire Work & 3.29 \\
\hline 3 & & Believe and Accept & 3.54 \\
\hline 4 & \multirow{3}{*}{ Continuous Commitment } & Belief & 2.19 \\
\hline 5 & & Willingness to Try & 3.00 \\
\hline 6 & & Strong Attachment & 2.97 \\
\hline 7 & \multirow{3}{*}{ Normative Commitment } & Employee's Inclination & 3.40 \\
\hline 8 & & Employee's Loyalty & 3.46 \\
\hline 9 & & Employee's Pride & 3.60 \\
\hline \multirow{2}{*}{\multicolumn{3}{|c|}{$\begin{array}{l}\text { Total } \\
\text { Average }\end{array}$}} & 28.91 \\
\hline & & & 3.21 \\
\hline
\end{tabular}

Table-3. Variable description implementation of internal control system.

\begin{tabular}{l|l|l|c}
\hline No. & Dimention & Indicator & Average \\
\hline 1 & Control & Inspection & 3.87 \\
\cline { 3 - 4 } 2 & Environment & Competency Standards & 4.00 \\
\hline 3 & \multirow{2}{*}{ Risk Assessment } & Risk Analysis & 3.91 \\
\cline { 3 - 4 } & & Management Plan & 4.03 \\
\hline 4 & \multirow{2}{*}{ Control Activities } & Safety & 4.14 \\
\cline { 3 - 4 } & \multirow{2}{*}{\begin{tabular}{l} 
Comformation and \\
\cline { 3 - 4 }
\end{tabular}} & Development & 4.03 \\
\cline { 3 - 4 } & Information & 4.08 \\
\hline 7 & Mccountability & 4.20 \\
\hline 9 & Monitoring & Follow-up & 4.37 \\
\cline { 3 - 4 } & & Evaluation & 4.11 \\
\hline \multirow{2}{*}{$\begin{array}{l}\text { Total } \\
\text { Average }\end{array}$} & & 4.0 .77 \\
\hline
\end{tabular}

Table 2 shows that organizational commitment has an average value of 3.21. This result indicates that the respondents agreed that organizational commitment is very necessary for performing a profession to generate 
improved work performance and an advanced career. The result also indicates that the organizational commitment at the Regional Working Unit in South Tangerang is excellent.

The table below describes an analysis of the internal control system implementation.

Based on Table 3, it can be seen that the implementation of the internal control system has an average value of 4.07. This number proves that the implementation of the internal control system has been effectively implemented at the Regional Working Units in South Tangerang.

The following table describes the accounting comprehension.

Table-4. Variable description accounting comprehension.

\begin{tabular}{|c|c|c|c|}
\hline No. & Dimension & Indicator & Average \\
\hline 1 & \multirow{5}{*}{$\begin{array}{l}\text { Steps of } \\
\text { Accounting Cycle }\end{array}$} & Recording & 4.14 \\
\hline 2 & & Grouping & 4.08 \\
\hline 3 & & Summarizing & 3.94 \\
\hline 4 & & Reporting & 4.11 \\
\hline 5 & & Interpretation & 4.17 \\
\hline \multirow{2}{*}{\multicolumn{3}{|c|}{$\begin{array}{l}\text { Amount } \\
\text { Average }\end{array}$}} & 20.46 \\
\hline & & & 4.09 \\
\hline
\end{tabular}

Table 4 shows that accounting comprehension has an average value of 4.09. This result shows that the employee who compiles the financial statements has completed all financial reports so that there is no error in the process of summarizing accounting data. The results also indicate that the Regional Working Units in South Tangerang have a good performance in organizing financial statements.

The following table is a descriptive analysis of financial reports quality.

Table-5. Variables description quality of financial report.

\begin{tabular}{|c|c|c|c|}
\hline No. & Dimensions & Indicators & Average \\
\hline 1 & \multirow{4}{*}{ Relevant } & Benefits of Feedback & 4.20 \\
\hline 2 & & Predictive benefits & 4.23 \\
\hline 3 & & Reliable & 4.11 \\
\hline 4 & & Complete and accurate & 4.28 \\
\hline 5 & \multirow{4}{*}{ Reliable } & Honest presentation & 4.23 \\
\hline 6 & & Verifiable & 4.37 \\
\hline 7 & & Neutrals & 4.14 \\
\hline 8 & & Impartial information on financial statements & 4.14 \\
\hline 9 & \multirow{2}{*}{ Compareable } & Internal and external comparisons & 4.26 \\
\hline 10 & & SAP compliant & 4.17 \\
\hline 11 & \multirow{2}{*}{ Understandable } & Limits of understanding & 4.20 \\
\hline 12 & & Valuable & 4.06 \\
\hline \multirow{2}{*}{\multicolumn{3}{|c|}{$\begin{array}{l}\text { Amount } \\
\text { Average }\end{array}$}} & 50.40 \\
\hline & & & 4.20 \\
\hline
\end{tabular}

Based on Table 5, it can be seen that the quality of financial statements has an average value of 4.20. This shows that the financial statements used as communication materials between the organization and external parties are understandable, valuable, and verifiable. It indicates that the financial reports of Regional Working Units in South Tangerang has good quality.

The following table presents a descriptive analysis of public accountability.

Table 6 shows that public accountability has an average value of 4.20. It indicates that the respondents agreed that the delivery of quality and up-to-date financial statements can increase public accountability. 


\subsection{Evaluating the Outer Model}

\subsubsection{Validity Test and Reliability Test}

The following picture is the result of the output loading factor from the construct of organizational commitment, the implementation of internal control systems, accounting comprehension, financial reports quality, and public accountability in the Smart PLS application.

Table-6. Variables description public accountability.

\begin{tabular}{|c|c|c|c|}
\hline No. & Dimensions & Indicators & Average \\
\hline 1 & \multirow{2}{*}{$\begin{array}{l}\text { Legal Accountability and } \\
\text { Honesty }\end{array}$} & Compliance & 4.34 \\
\hline 2 & & Corruption Avoidance & 4.40 \\
\hline 3 & \multirow{4}{*}{ Managerial Accountability } & Organizational Management & 4.25 \\
\hline 4 & & Implementing Accountability & 4.23 \\
\hline 5 & & Accountability for Performance & 4.23 \\
\hline 6 & & Activity Achievement & 4.23 \\
\hline 7 & \multirow{2}{*}{ Program Accountability } & Program Accountability & 4.28 \\
\hline 8 & & Program Objectives & 4.17 \\
\hline 9 & \multirow{2}{*}{ Accountability Policy } & Objectives & 4.14 \\
\hline 10 & & Policy Accountability & 4.14 \\
\hline 11 & \multirow{4}{*}{ Financial accountability } & Periodic Reports & 4.20 \\
\hline 12 & & Annual Report & 4.23 \\
\hline 13 & & Funds Liability & 4.17 \\
\hline 14 & & Publication of Reports & 3.82 \\
\hline \multirow{2}{*}{\multicolumn{3}{|c|}{$\begin{array}{l}\text { Amount } \\
\text { Average }\end{array}$}} & 58.86 \\
\hline & & & 4.20 \\
\hline
\end{tabular}

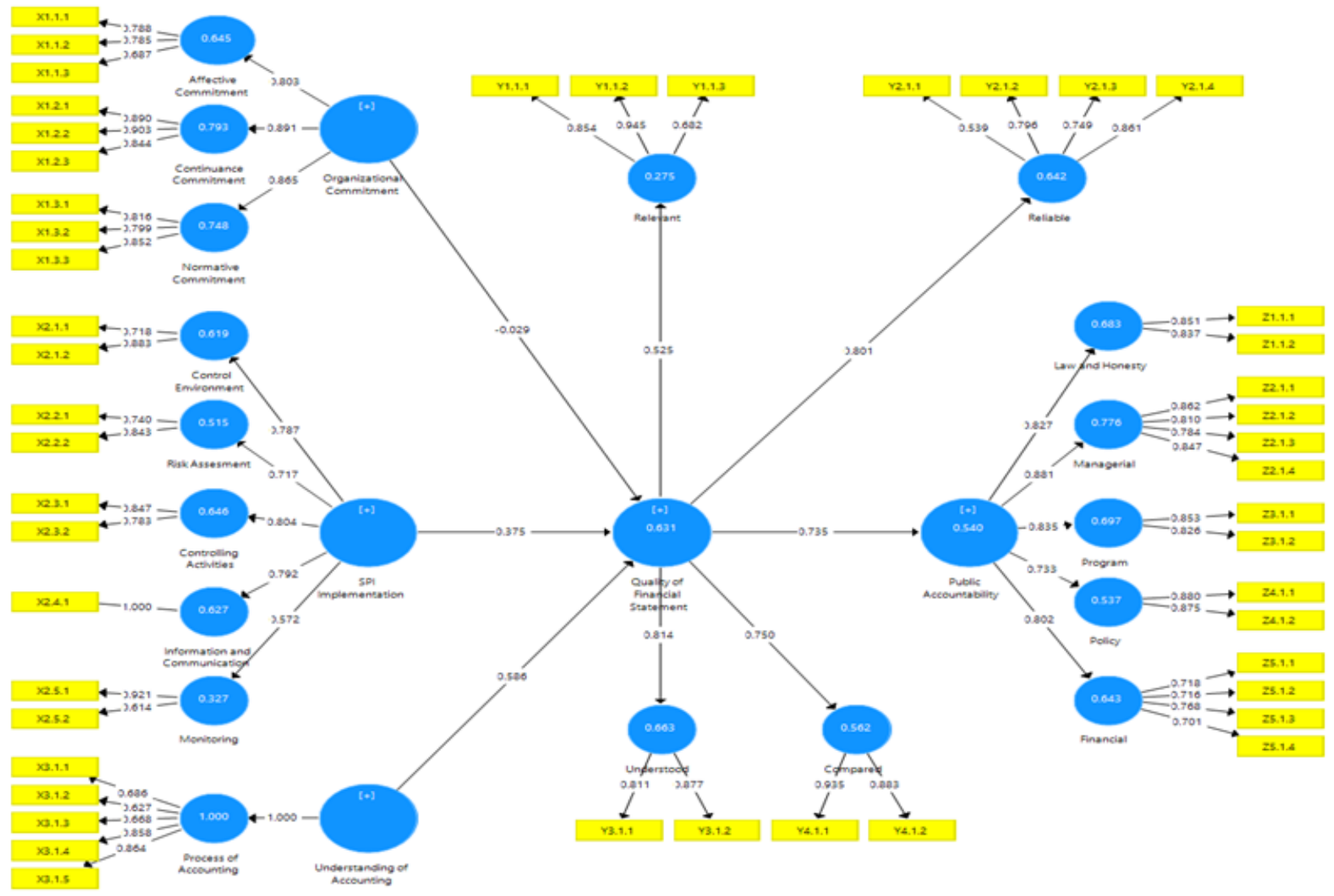

Figure-2. Output Loading Factor Research.

The validity test on the five variables shows the value of Average Variance Extract (AVE) is greater than 0.5 , it indicates that there is no problem with discriminant validity. Table 7 presents the results of the discriminant validity test. 
Table-7. Test result of discriminant validity.

\begin{tabular}{l|l|c}
\hline No & Variable & Average \\
\hline 1. & Organizational commitments & 0.674 \\
\hline 2. & Implementation of Internal Control System & 0.531 \\
\hline 3. & Accounting Comprehension & 0.611 \\
\hline 4. & Quality Financial Report & 0.610 \\
\hline 5. & Public accountability & 0.732 \\
\hline
\end{tabular}

The reliability test on the five variables showed Composite Reliability values above 0.7 and Cronbach's Alpha above 0.6, this means that the indicators used in each dimension had good reliability or were able to measure the construct. Table 8 presents the results of the reliability test.

Table-8. The Result of reliability test.

\begin{tabular}{l|c|c|c}
\hline Variable \& Dimensions & Cronbach's Alpha & Composite Reliability & Description \\
\hline Organizational Commitment (X1) & 0.876 & 0.884 & Reliable \\
\hline Application of SPI (X2) & 0.790 & 0.856 & Reliable \\
\hline Accounting Comprehension (X3) & 0.797 & 0.861 & Reliable \\
\hline Quality Financial report (Y) & 0.819 & 0.869 & Reliable \\
\hline Public Accountability (Z) & 0.893 & 0.912 & Reliable \\
\hline
\end{tabular}

\subsection{Evaluating Inner Model}

Evaluation of inner model measured by using value predictive relevance $\left(\mathrm{Q}^{2}\right)$. The result of the predictive relevance value $\left(\mathrm{Q}^{2}\right)$ displayed on the Table 9.

Table-9. Predictive Relevance $\left(Q^{2}\right)$

\begin{tabular}{l|c}
\hline Variable & R. Square \\
\hline Quality Financial Report & 0.620 \\
\hline Public accountability & 0.647 \\
\hline Predictive Relevance & 0.866 \\
\hline
\end{tabular}

After the R-square value is entered in the Formula predictive relevance, the result of the value $\mathrm{Q}^{2}$ are: 0.866 which means the evaluation of the inner model is good at explaining the quality variables of financial statements and public accountability. Based on the coefficient of determination in the table above, it shows that $62 \%$ financial report quality can be explained by organizational commitments, implementation of internal control system and accounting comprehension, while $38 \%$ is explained by other variables outside of the research. The $64.7 \%$ value of coefficient of public accountability is caused by organizational commitments, implementation of internal control system and accounting comprehension, while another $35.3 \%$ is affected by external factor of this study. The value of predictive relevance on this research model by 0.866 or $86.6 \%$ which means the model can explain the phenomenon of public accountability attributed to the quality of financial statements, organizational commitments, implementation of internal control system and accounting comprehension. This research model can be categorized as excellent so that it can be used to testing the hypothesis.

\subsection{Hypothesis Testing}

The hypotesis testing in this study is based on the output of Smartpls ver 3.0 software. The testing hypothesis criteria of the study use a 5\% signification level which means the level of confidence of the study is $95 \%$ and the probability of error is $5 \%$. Since it uses a significant $5 \%$ on hypothesis testing, the if the value is smaller than $0.05 \mathrm{H}_{\mathrm{a}}$ is accepted and $\mathrm{H}_{\mathrm{o}}$ is rejected. The following picture describe the path diagram for the results of testing the hypothesis. 


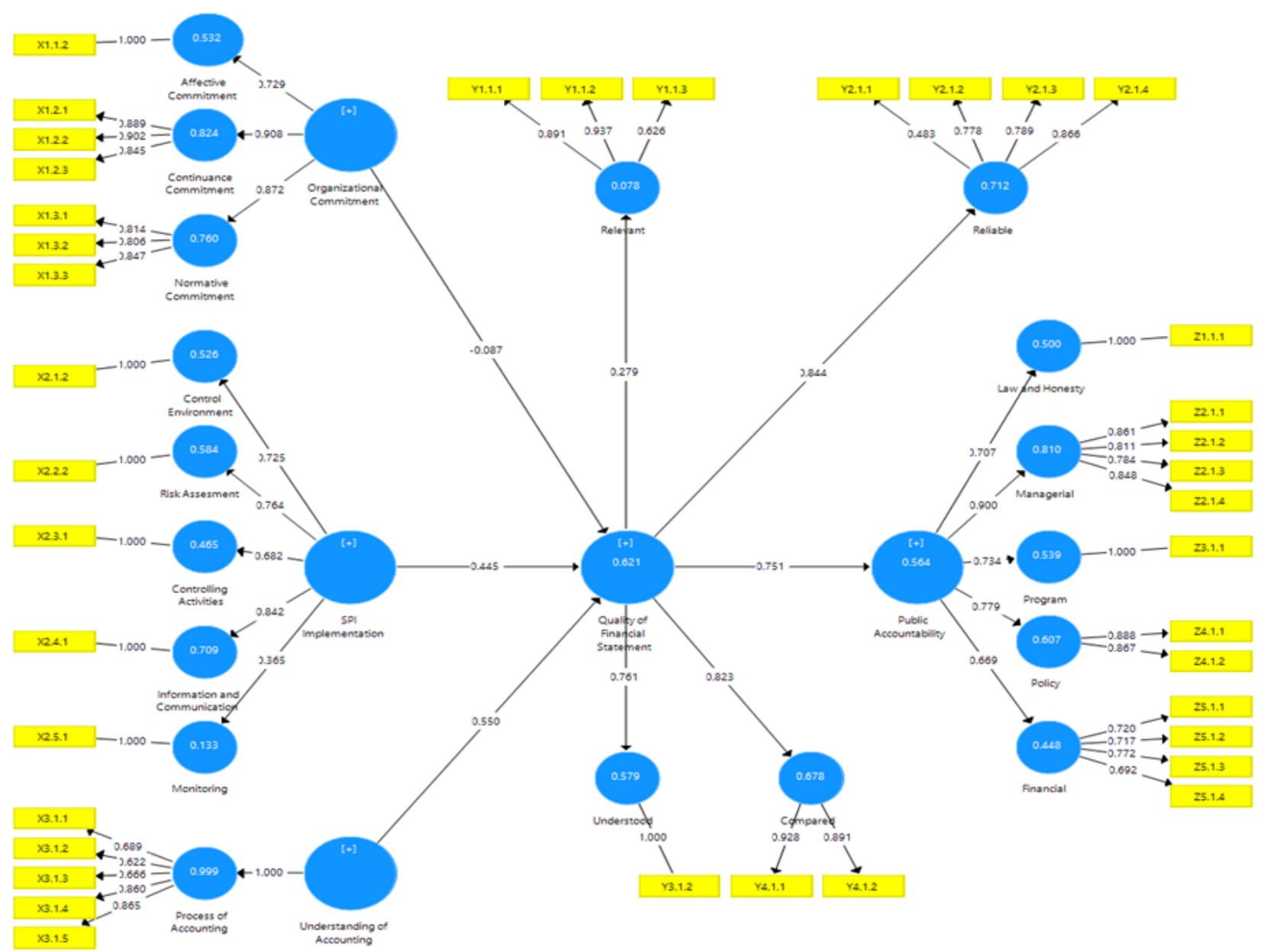

Figure-3. Hypothesis testing path diagram.

Based on the figure above, the entire dimension in each variable is capable of measuring each construction because it has a $\mathrm{T}_{\text {statistical }}$ value greater than $\mathrm{T}_{\text {table }}$ of 2.042. To examine the significance of each variable by looking at the parameter coefficient value and the significance $\mathrm{T}_{\text {statistical }}$ value. Table 10 presents hypothesis testing results.

Table-10. Hypothesis testing results

\begin{tabular}{l|l|c|c|c|c}
\hline No & Relationships between variables & $\begin{array}{l}\text { Standard } \\
\text { Deviation }\end{array}$ & T Stats & P Values & Description \\
\hline H1 & $\begin{array}{l}\text { Organizational Commitment-> } \\
\text { Quality Financial report }\end{array}$ & 0.108 & 0.802 & 0.423 & Not significant \\
\hline H2 & $\begin{array}{l}\text { Application of SPI-> Quality of } \\
\text { financial statements }\end{array}$ & 0.160 & 2.782 & 0.006 & Significant \\
\hline H3 & $\begin{array}{l}\text { Accounting Comprehension-> } \\
\text { Quality Financial report }\end{array}$ & 0.135 & 4.071 & 0.000 & Significant \\
\hline H4 & $\begin{array}{l}\text { Financial report Quality-> Public } \\
\text { accountability }\end{array}$ & 0.087 & 8.600 & 0.000 & Significant \\
\hline
\end{tabular}

The organizational commitment variable does not significantly influence the quality of financial statements with a $\mathrm{P}_{\text {values }}$ value greater than the significance level (0.05) of 0.423 and statistical value of $0.802<\mathrm{T}_{\text {table }}$ of 2.042 . The variable implementation of the internal control system has a significant effect on the quality of financial statements with a value of $\mathrm{P}_{\text {values }}$ that is smaller than the significance level (0.05) of 0.006 and statistical value of $2.782>\mathrm{T}_{\text {table }}$ of 2.042. The accounting comprehension variable has a significant influence on the quality of financial

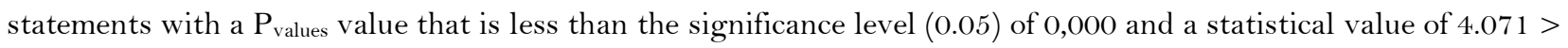
$\mathrm{T}_{\text {table }}$ of 2.042. Variable quality of financial statements has a significant impact on public accountability with a $\mathrm{P}_{\text {values }}$ value that is smaller than the significance level (0.05) of 0,000 and statistical value of $8,600>\mathrm{T}_{\text {table }}$ of 2,042 . 


\section{DISCUSSION}

The results of the first hypothesis conclude that the organizational commitment have no significant effect on the quality of financial statements. The absence of organizational commitment to the quality of financial statements is likely due to the low level of employee involvement in the organization. Organizational commitment can be created if the organization, especially the leader gives encouragement, appreciates contributions, and gives appreciation to employees/staff at work. Conceptually, if an individual is highly committed to the goals of the organization, it can affect his actions and performance to produce qualified financial reports. Vice versa, if an individual does not have a high commitment to the organization, then his capability will not give qualified financial reports. This study is in line with Siwambudi, Yasa, and Badera (2017) and Rinie, Pranata, and Rapina (2019) which states that organizational commitment does not affect the quality of financial statements, in contrast to Istri et al. (2017) who find the results that organizational commitment is an influential positive and significant impact on the quality of financial statements.

The second hypothesis reveals that the implementation of the internal control system has a significant effect on the quality of financial statements. Adequate internal control will affect the quality of financial reporting. The government internal control system is a policy and procedure designed to provide adequate confidence for management that the organization can achieve its goals and targets (Rai, 2011). The implementation of an excellent internal control system will create more qualified financial reports. A good internal control system in a government can be a guarantee for government institutions to achieve the stated goals and generate reliable financial reports. This research is in line with Herawati (2014) and (Trisnawati \& Wiratmaja, 2018) which states that the implementation of internal control systems has a significant influence on the quality of financial statements, while Setiyawati (2013); Purnomo (2014) and Nurlis (2018) mentioned that the result of the implementation of internal control system does not affect the quality of the financial statements.

The third hypothesis concludes the result that accounting comprehension significantly influences the quality of financial statements. Someone who has an accounting comprehension is required in processing financial management to produce high-quality financial reports. In the process of compiling local government financial reports, it not only requires accounting comprehension but also qualified human resources. The human resources have to comprehend and have good competence in government accounting, regional finance, and also in organizational governance. This research is in line with Aniftahudin et al. (2016) and Purwanti and Wasman (2016) which states that the accounting comprehension has a positive effect on the quality of financial statements.

The outcome of the fourth hypothesis shows that the quality of financial statements has a significant influence on public accountability. One of the regional government accountabilities is presenting financial reports. A high-quality financial report is one of the liabilities of the government in carrying out accountability and as a foundation for decision making. A well presented financial statement will explain the financial reporting of the local government because all financial transactions are recorded by the presented evidence so that the presentation of financial statements that will be honestly and completely presented will have an impact on increasing the accountability of regional financial management. This is in line with research conducted by Iskandar and Setiyawati (2015) and Djalil et al. (2017) which states that the quality of financial statements affects public accountability.

\section{CONCLUSION AND SUGGESTION}

According to the research findings and discussion, it can be concluded that organizational commitment has no significant effect on the quality of financial statements, while the implementation of internal control systems and 
accounting comprehension have significantly influenced the quality of financial statements and the quality of financial statements has a significant impact on the quality of financial statements.

Based on the results of the study and conclusions, it can be suggested that the research findings of this study have implications for the Regional Working Units (SKPD) in South Tangerang on how to create high-quality financial reports and obtain public accountability. It is expected that the SKPD can generate a compensation system that makes employees feel appreciated. Not only material compensation but organizations also need to build emotional relationships so that employees feel valued as part of the organization and make them feel that they have an essential role in the organization so that the employees can well cooperate and the employee commitment will also raise. In addition, the organization needs to improve the effectiveness of the internal control system and be attentive to the financial statement management resources so that the information in the financial statements has high-quality that will have a great influence on the organization.

Funding: This study received no specific financial support.

Competing Interests: The authors declare that they have no competing interests.

Acknowledgement: Both authors contributed equally to the conception and design of the study.

\section{REFERENCES}

Abiola, I., \& Oyewole, A. T. (2013). Internal control system on fraud detection: Nigeria experience. Journal of Accounting and Finance, 13(5), 141-152.

Aniftahudin, A., Kamaliah, K., \& Hanif, R. (2016). The influence of accounting understanding, local government financial accounting systems and information technology on the quality of local government financial reports (Study at SKPD Indragiri Hilir Regency). Online Journal of Students of the Faculty of Economics, University of Riau, 3(1), 935-949.

Arens, A. J. (2006). Indonesian edition auditing, translated by Amir Abadi Yusuf. Jakarta: Salemba Empat.

Baldwin, B. R. (2013). Managing organizational behavior (2nd ed.). New York: McGraw- Hill Education.

Bastian, I. (2010). Public sector accounting: An introduction. Jakarta: Salemba.

Djalil, M., Nadir, N., \& Fatmi, L. (2017). Influence of implemention of government accounting standard and the effectiveness of government's internal control system on the quality of local financial report and its impact toward the accountability of reginonal financial management (A Research on Go. Reseach Journal of Finance and Accounting, 8(4), 106-1 14.

Herawati, T. (2014). The influence of internal control systems on the quality of financial statements (Surveys at the Cianjur Regional Government Organizations). Star - Study \& Accounting Research, 11(1), 1-14.

Hery. (2016). Financial statement analysis. Jakarta: Grasindo.

Iman, M. (2010). Management and human life. Jakarta: Salemba Empat.

Iskandar, D., \& Setiyawati, H. (2015). The effect of internal accountants' competence on the quality of financial reporting and the impact on the financial accountability. International Journal of Managerial Studies and Research, 8(5), 55-64.

Istri, C., Prami, A., Made, N., \& Erawati, A. (2017). The influence of HR quality, utilization of information systems, internal control and organizational commitment on the quality of financial statements. E-Journal of Accounting, 21(2), 11861205.

Ivano, Y. (2009). The influence of motivation and organizational commitment to performance employees (studies at the BPN land office Semarang City). Thesis. Universitas Diponegoro Semarang.

KBBI (Kamus Besar Bahasa Indonesia). (2005). Jakarta: PT (Persero) Publishing and Printing.

Kusumaputri, E. S. (2015). Commitment to organizational change (Organizational Change in Islamic Perspective and Psychology). Yogyakarta: Deepublish.

Luthans, F. (2011). Organizational behavior: An evidence-based approach. New York: Mcgraw-Hill.

Mahmudi. (2006). Financial statement analysis regional government. Guide for executive, DPRD and community in economic, social decision making and politics. Yogyakarta: YKPN School of Management. 
Mahmudi. (2015). Public sector performance management. Yogyakarta: YKPN School of Management.

Mardiasmo. (2009). Public sector accounting. Yogyakarta: Andi.

Mulyadi. (2014). Accounting system. Jakarta: Salemba Empat.

Mursyidi. (2009). Government accounting in Indonesia. Bandung: PT.Refika Aditama.

Mursyidi. (2010). Basic accounting. Surabaya: Ghalia Indonesia.

Mursyidi. (2013). Government accounting in Indonesia (Printing to). Bandung: Refika Aditama.

Nurlis, N. (2018). The effect of the government accounting standards implementation and apparatus competency on the quality of the local government financial reporting (Case Study at Klaten District Government). Research Journal of Finance and Accounting, 9(8), 63-69.

Nurlis, N., \& Winwin, Y. (2017). The influence of internal control effectiveness, information technology utilization and human resources competence on local government financial reporting quality (Survey on SKPD Banten Provincial Government and Serang City). Research Journal of Finance and Accounting, 8(12), 111-124.

Purnomo, B. S. (2014). The influence of internal control systems and coercive power on the quality of local government financial reports. Journal of Accounting and Financial Research, 2(1), 276-288. Available at: https://doi.org/10.17509/jrak.v2i1.6581.

Purwanti, M., \& Wasman, W. (2016). The influence of accounting understanding, utilization of accounting information systems and the role of internal audit on the quality of financial statements (Survey on the Employee Cooperative of the Republic of Indonesia, Bandung City). Journal of Business and Management, 4(3), 61-75.

Rai, I. G. A. (2011). Public sector performance audits. Jakarta: Salemba.

Rakhmat. (2018). Public administration and accountability. Yogyakarta: Andi.

Reeve, J. M., Carls, S. W., \& Fees, J. E. D. (2013). Introduction to Indonesian adaptation accounting (Book 1). Translated by: Damayanti Dian. Jakarta: Salemba Empat.

Rinie, R., Pranata, V. M., \& Rapina, R. (2019). The effect of internal control and organizational commitment on the quality of financial reporting (Survey on Textile Companies in Bandung and its Surroundings. Journal of Accounting, Finance, Taxation, and Auditing, 1(1), 15-30.

Robbins, S. P., \& Judge, T. A. (2009). Organizational behavior (translator Diana Angelica, Ria Cahyani, and Abdul Rosyid). Jakarta: Salemba Empat.

Rommy, A. (2011). The effect of commitment organization and organizational culture on the performance of government agencies area. Skripsi: Fakultas Ekonomi. Universitas Negeri Padang.

Setiyawati, H. (2013). The effect of internal accountants' competence, managers' commitment to organizations and the implementation of the internal control system on the quality of financial reporting. International Journal of Business and Management Invention, 2(11), 19-27.

Siwambudi, I. G. N., Yasa, G. W., \& Badera, I. D. N. (2017). Organizational commitment as moderator effect of HR competence and internal control systems on the quality of financial statements. E-Journal of Economics and Business, Udayana University, 6(1), 385-416.

Stephen, P. R., \& Timothy, A. J. (2011). Organizational behavior. Jakarta: Salemba.

Sugandi, J. D., \& Hanif, R. A. (2013). The effect of human resource capacity, utilization of information technology, accounting internal control, and organizational commitment to reliability regional government financial reporting (survey on SKPD throughout Kuansing Regency). Accounting Journal FE: Riau University, 1(1), 1-14.

Suwardjono. (2005). Accounting theory: Engineering financial reporting. Yogyakarta: BPFE.

Thomas, R. R., Henny, V. G., Elaine, H., \& Michael, A. B. (2009). International financial statement analysis. New Jersey: John Willey and Sons, Inc.

Trisnawati, N. N., \& Wiratmaja, D. N. (2018). Effect of human resource quality and internal control system on the quality of local government financial reports. E-Journal of Accounting, 24(1), 29. Available at: https://doi.org/10.24843/eja.2018.v24.i01.p29. 
Warisno. (2008). The factors that are affect performance device work unit region (SKPD) in government environment jambi province. Thesis. Sekolah Pascasarjana USU. Medan.

Wibowo. (2017). Work management. Jakarta: Rajawali Pers.

Yulianani, S., Nadirsyah, N., \& Bakar, U. (2010). Internal audit of the quality of local government financial reports (Study at the Banda Aceh City Government). Journal of Accounting Research \& Research, 3(2), 206-220.

Views and opinions expressed in this article are the views and opinions of the author(s), International Journal of Asian Social Science shall not be responsible or answerable for any loss, damage or liability etc. caused in relation to/arising out of the use of the content. 